\title{
The Common Approaches of Nitrogen Removal in Bioretention System
}

\author{
Wafaa Ali *(D), Husna Takaijudin, Khamaruzaman Wan Yusof, Manal Osman (D) and \\ Abdurrasheed Sa'id Abdurrasheed
}

check for updates

Citation: Ali, W.; Takaijudin, H.; Yusof, K.W.; Osman, M.; Abdurrasheed, A.S. The Common Approaches of Nitrogen Removal in Bioretention System. Sustainability 2021, 13, 2575. https://doi.org/ $10.3390 /$ su13052575

Academic Editor: Vincent Linderhof

Received: 16 December 2020

Accepted: 1 February 2021

Published: 27 February 2021

Publisher's Note: MDPI stays neutral with regard to jurisdictional claims in published maps and institutional affiliations.

Copyright: (c) 2021 by the authors. Licensee MDPI, Basel, Switzerland. This article is an open access article distributed under the terms and conditions of the Creative Commons Attribution (CC BY) license (https:// creativecommons.org/licenses/by/ $4.0 /)$.
Department of Civil and Environmental Engineering, Universiti Teknologi PETRONAS, Bandar Seri Iskandar, Perak 32610, Malaysia; husna_takaijudin@utp.edu.my (H.T.); khamaruzaman.yusof@utp.edu.my (K.W.Y.); manal_17005662@utp.edu.my (M.O.); abdurrashee_16000331@utp.edu.my (A.S.A.)

* Correspondence: wafaa_19001087@utp.edu.my

\begin{abstract}
Bioretention is considered one of the best management practices (BMPS) for managing stormwater quality and quantity. The bioretention system has proven good performance in removing total suspended solids, oil, and heavy metals. The nitrogen $(\mathrm{N})$ removal efficiency of the bioretention system is insufficient, however, due to the complex forms of nitrogen. Therefore, this paper aims to review recent enhancement approaches to nitrogen $(\mathrm{N})$ removal and to discuss the factors influencing bioretention efficiency. To improve bioretention efficiency, several factors should be considered when designing bioretention systems, including nitrogen concentration, climate factors, and hydrological factors. Further, soil and plant selection should be appropriate for environmental conditions. Three design improvement approaches have been reviewed. The first is the inclusion of a saturated zone (SZ), which has been used widely. The SZ is shown to have the best performance in nitrogen removal. The second approach (which is less popular) is the usage of additives in the form of a mixture with soil media or as a separated layer. This concept is intended to be applied in tropical regions with wet soil conditions and a short dry period. The third approach combines the previous two approaches (enhanced filter media and applying a SZ). This approach is more efficient and has recently attracted more attention. This study suggests that further studies on the third approach should be carried out. Applying amendment material through filter media and integrating it with SZ provides appropriate conditions to complete the nitrogen cycle. This approach is considered a promising method to enhance nitrogen removal. In general, the bioretention system offers a promising tool for improving stormwater quality.
\end{abstract}

Keywords: stormwater quality; bioretention; nitrogen; saturated zone; additives

\section{Introduction}

Urbanization and population growth are rapidly increasing with 7.2 billion people in the world, and more people are living in cities rather than in rural areas [1]. The expansion of impervious areas causes an increase in flood events and negatively affects stormwater quality. The issue of stormwater quality has received considerable attention and is known as the primary source of ecological contamination. To make matters worse, impervious areas, including streets, rooftops, car park areas, and buildings, affect stormwater quality by impeding the natural process of filtration through ground layers. Figure 1 shows stormwater precipitation (rainfall and snowmelt), whereby in a natural situation, a small amount of rainfall flows as surface runoff. In the case of an urban situation, a large amount of rainfall is converted to surface runoff [1]. Rain runoff passing over impervious surfaces carries pollutants from human activities before eventually reaching the groundwater by infiltration and settling in rivers, wetlands, lakes, etc. Runoff flow on impervious surfaces containing accumulated pollutants leads to nonpoint source pollution [2]. Therefore, nonpoint source pollutants caused by stormwater runoff are one of the main challenges of stormwater management [3]. 

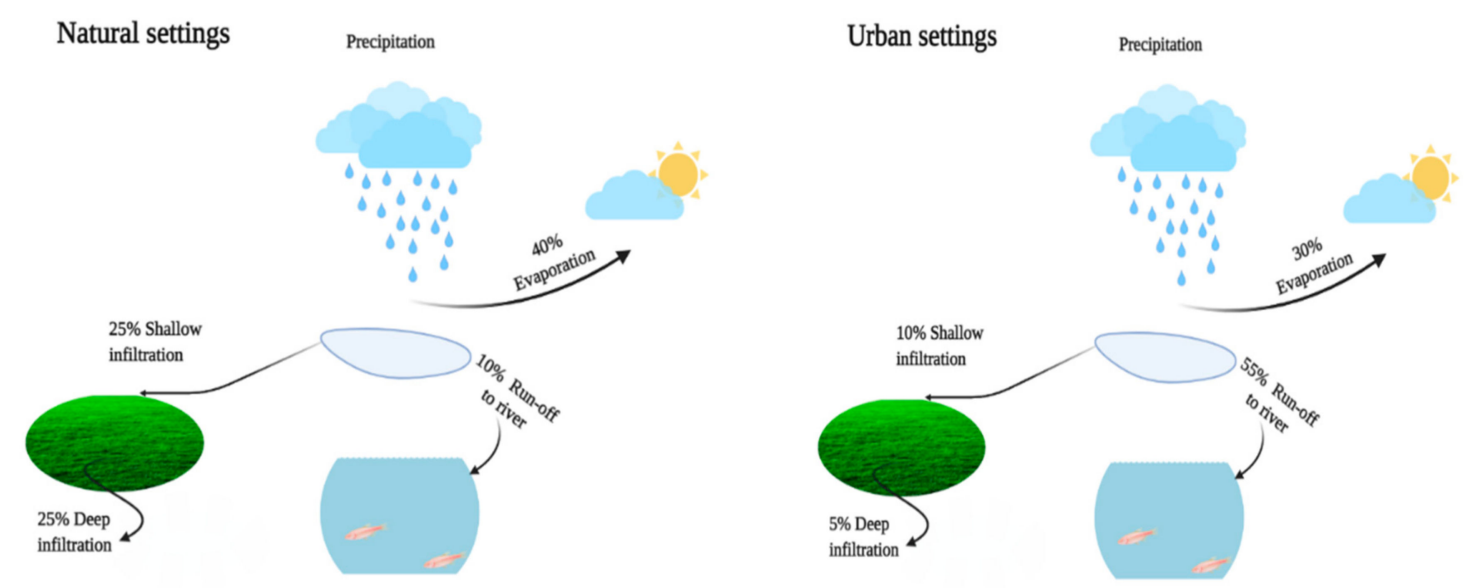

Figure 1. A comparison between the surface runoff of natural and urban surfaces.

Pollutants in stormwater runoff are classified into gross pollutants and dissolved pollutants [4]. Gross pollutants comprise agricultural and industrial wastes such as paper, bottles, plastic bags, leaves, and others [5]. Dissolved pollutants, on the other hand, contain nutrients, heavy metals, and hydrocarbons [6-8]. The dissolved form accounts for half of the pollutants in stormwater [7]. Existing pollutants in stormwater runoff such as nitrogen (N) have a harmful impact on the ecosystem, which leads to a decline in aquatic species, eutrophication, and harmful algal blooms [9]. Therefore, it is essential to decrease these nutrients in the stormwater runoff for environmental quality and water reuse [10].

Nevertheless, removing nitrogen $(\mathrm{N})$ from stormwater poses a great challenge [11]. The removal of $\mathrm{N}$ would cost billions of dollars [12]. Thus, it is important to find costeffective and environmentally sustainable solutions to mitigate the nitrogen threat to the ecological system. The stormwater management system is used worldwide to control stormwater quality and quantity. The main aim of stormwater management is the elimination of pollutants and runoff quantity [13]. Stormwater pollution can be reduced by applying advanced approaches such as Low-Impact Development (LID) and Best Management Practices (BMPs). In recent decades, these practices have attracted urban planners and city managers $[14,15]$. Some of these practices have been used to increase pervious surfaces and enhance rainfall infiltration. In the United Kingdom (UK), such a practice is employed in the Sustainable Urban Drainage System (SUDS). The Sustainable Urban Drainage System (SUDS) is divided into twelve types, namely (1) grassed swales, (2) infiltration trenches, (3) permeable pavements, (4) wet ponds, (5) bioretention zones, (6) tree boxes, (7) sand filters, (8) constructed wetlands, (9) soak ways, (10) infiltration basins, (11) extended dry detention basins, and (12) rain barrels and cisterns [16]. These devices must be maintained from time to time to achieve the best results. A similar concept is used in the US and Australia, namely Low Impact Development (LID) and Water Sensitive Urban Design (WSUD), respectively. Studies revealed that the effectiveness of most devices of LID will decrease over time if maintenance is neglected [17,18]. Lindsey et al. [17] tested the efficiency of different kinds of practices (infiltration trenches, infiltration basins, vegetated swales, dry wells, and porous pavement), and their study revealed that infiltration basins and porous pavement were shown to be less effective and needed more maintenance compared to dry wells and trenches. Moreover, maintenance is essential in tropical and subtropical countries to avoid diseases [19]. In Malaysia, the Department of Irrigation and Drainage (DID) has introduced the Urban Stormwater Management Manual (Manual Saliran Mesra Alam) 2012 [20]. The Manual was designed based on three primary pollutants characterizing runoff water, which are gross pollutants, total suspended solids (TSS), and nutrients, and particularly, total nitrogen (TN).

The bioretention system is one of the most favorable and frequently used in SUDS. It plays a key role in the degradation of stormwater pollutants, including suspended solids, heavy metals (zinc, lead, etc.), phosphorus, nitrogen, and oil [21-23]. The bioretention 
system is considered a favourable technology in terms of cost and effectiveness in removing pollutants. Additionally, this technology provides an aesthetic view. A field test comprising a combination of bioretention and swale was conducted in Hubai, China [24]. The results indicated that the stormwater peak flow reduction of a bioretention cell was more significant than the swale. The bioretention system is considered a promising tool to enhance stormwater quality $[16,25]$.

Nevertheless, previous studies have demonstrated that a traditional bioretention system has not achieved good nitrogen removal, especially for nitrate $\left(\mathrm{NO}_{3}\right)[26,27]$. Understanding the complexity of a bioretention system is paramount for developing bioretention guidelines [28]. Although the performance of bioretention systems has been surveyed in many review articles $[4,28,29]$, the popular approaches of nitrogen removal are yet to be adequately covered. Thus, this study was introduced to provide a clear view for researchers about the enhancement methods for nitrogen removal in bioretention system.

\section{Overview of Bioretention System}

Biofilters, which are also known as rain gardens or bioretention systems, are commonly adopted best-management practices (BMPs) [30]. In recent years, they have elicited more attention not only due to their stormwater quality and quantity management ability [31-33] but also because of the benefits they have for human health and the ability to mitigate the heat island effect $[34,35]$. Biofilters provide a cooling climate by means of evapotranspiration. A bioretention cell includes several items from bottom to top: gravel, sand, soil, and mulch, as well as plant species $[13,31,36]$. Stormwater is treated via a bioretention system through several processes. These include physical infiltration and retention; chemical adsorption and sedimentation; and biological plant uptake and microbial activity [37]. Figure 2 illustrates the various components of a traditional bioretention system.

The bioretention approach is a sustainable solution which may be applied to either individual or regional systems [38]. However, conventional bioretention systems are insufficient for removing nitrogen [39]. A lacking denitrification process results in nitrogen removal being unstable and widely variable in the bioretention system, particularly for nitrate $\left(\mathrm{NO}_{3}\right)$. Nitrogen removal is considered the main challenge encountered by bioretention designers [39-41]. Davis et al. [30] conducted a laboratory study on the performance of traditional bioretention systems on nutrient removal. The results showed the reduction of total Kjeldahl nitrogen (TKN) and ammonium $\left(\mathrm{NH}_{4}\right)$ to be $60 \%$ to $80 \%$, while export nitrate $\left(\mathrm{NO}_{3}\right)$ was observed in some cases. The results of the field study undertaken by $\mathrm{L}$. $\mathrm{Li}$ and Davis demonstrated that particulate organic nitrogen (PON), ammonia $\left(\mathrm{NH}_{3}\right)$, and nitrite $\left(\mathrm{NO}_{2}\right)$ were effectively removed, while leaching in dissolved organic nitrogen (DON) and nitrate $\left(\mathrm{NO}_{3}\right)$ was observed [42]. Recently, different enhancement methods have been applied to achieve good nitrogen removal $[11,43,44]$. For example, it has been observed that the conventional system was less efficient than the modified media system with TN removal $56.6 \%$ and $61.3 \%$, respectively [7]. Inclusion of a saturated zone in bioretention system provides a better environment for the nitrogen cycle, thereby reducing effluent TN, while the leaching of nitrate still exists due to the ammonification of organic nitrogen which produces nitrate [11]. The efficiency of the conventional bioretention system in mitigating nitrogen depends on design factors, including the ratio of the bioretention surface area to the drainage area (SA/DA), filter media compositions, pollutant concentration, vegetation, and environmental factors [7,31]. Table 1 provides an overview of several studies on the conventional bioretention system, the efficiency of the bioretention system, and the disadvantages of each survey. 
Table 1. The literature on the conventional bioretention system.

\begin{tabular}{|c|c|c|c|c|c|c|c|c|}
\hline Plant & Soil Description & $\begin{array}{l}\text { Cell Depth } \\
(\mathrm{mm})\end{array}$ & Study Type & Study Description & Disadvantage & Results & $\begin{array}{c}\text { Site } \\
\text { Location }\end{array}$ & Ref. \\
\hline Creeping juniper plants & Sandy loam & $\begin{array}{l}610 \\
910\end{array}$ & $\begin{array}{c}\text { box prototypes } \\
\text { Small }(1070 \times 760) \\
\operatorname{Big}(3050 \times 1520) \mathrm{mm}\end{array}$ & $\begin{array}{l}\text { Indicate which soil } \\
\text { layer is more nutrient } \\
\text { removal by port } \\
\text { soil sampling }\end{array}$ & $\begin{array}{l}\text { Data nitrate removal of } \\
\text { small box not available due } \\
\text { to the experiment problem. }\end{array}$ & $\begin{array}{l}\text { Increasing TKN removal } \\
\text { with soil depth and high } \\
\text { removal in the lower layer, } \\
\text { Export } \mathrm{NO}_{3} \text { in the upper } \\
\text { layer and poor } \mathrm{NO}_{3} \text { removal } \\
\text { in lower soil depth. }\end{array}$ & USA & [30] \\
\hline No & $\begin{array}{l}\text { Fine sand, } \\
\text { sandy loam }\end{array}$ & 1000 & Column $(1050 \times 100) \mathrm{mm}$ & $\begin{array}{l}\text { Testing pollutant } \\
\text { concentration in } \\
\text { soil depth }\end{array}$ & $\begin{array}{l}\text { Clogging in fine media due } \\
\text { to absence of vegetation } \\
\text { and the need to maintain } \\
\text { the top layer of media. }\end{array}$ & $\begin{array}{l}\text { Significant N removal in top } \\
200 \mathrm{~mm} \text { soil depth and } \\
\text { leaching in lower layers due } \\
\text { to native soil wash. }\end{array}$ & Australia & [45] \\
\hline $\begin{array}{l}\text { Banksia (Banksia integrefolia), } \\
\text { Bottlebrush (Callistemon } \\
\text { pachyphyllus), Pigface (Carpobrotus } \\
\text { glaucesens), Flax Lily (Dianella } \\
\text { brevipedunculata), Swamp Foxtail } \\
\text { Grass (Pennisetum alopecurioides) }\end{array}$ & $\begin{array}{l}\text { Three soil } \\
\text { configurations: } \\
\text { Gravel, sand, } \\
\text { sandy loam }\end{array}$ & 1000 & $\begin{array}{c}\text { Mesocosm }(1000 \times 500 \times \\
500) \mathrm{mm}\end{array}$ & $\begin{array}{c}\text { Test ability of different } \\
\text { soil media to remove } \\
\text { nutrient }\end{array}$ & $\begin{array}{l}\text { Planted sand and planted } \\
\text { sandy loam are the best in } \\
\text { nitrogen removal than } \\
\text { other types. }\end{array}$ & $\begin{array}{l}\text { Planted sand and planted } \\
\text { sandy loam are the best } N \\
\text { removal without adding a } \\
\text { carbon source }\end{array}$ & Australia & [46] \\
\hline $\begin{array}{l}\text { Foxtail Grass (Pennisetum } \\
\text { alopecurioides), Flax Lily (Dianella } \\
\text { brevipedunculata), Banksia } \\
\text { (Banksia integrefolia), Bottle- brush } \\
\text { (Callistemon pachyphyllus) }\end{array}$ & $\begin{array}{l}\text { Sandy loam, loamy } \\
\text { sand and pea } \\
\text { gravel and } 200 \mathrm{~mm} \\
\text { loamy sand }\end{array}$ & 990 & Mesocosm & $\begin{array}{l}\text { Determine which } \\
\text { media type has good } \\
\text { nutrient removal and } \\
\text { interaction it with } \\
\text { vegetated and } \\
\text { non-vegetated } \\
\text { condition }\end{array}$ & $\begin{array}{l}\text { TN retention in vegetated } \\
\text { systems exceeded plant } \\
\text { uptake. This happened } \\
\text { with other processes which } \\
\text { are have not mentioned in } \\
\text { this study. }\end{array}$ & $\begin{array}{l}\text { NOx removal can happen } \\
\text { despite the absence of anox } \\
\text { condition and soil microbial } \\
\text { activity can do nitrification. } \\
\text { Planted loam system is the } \\
\text { best TN removal. }\end{array}$ & Australia & [37] \\
\hline
\end{tabular}




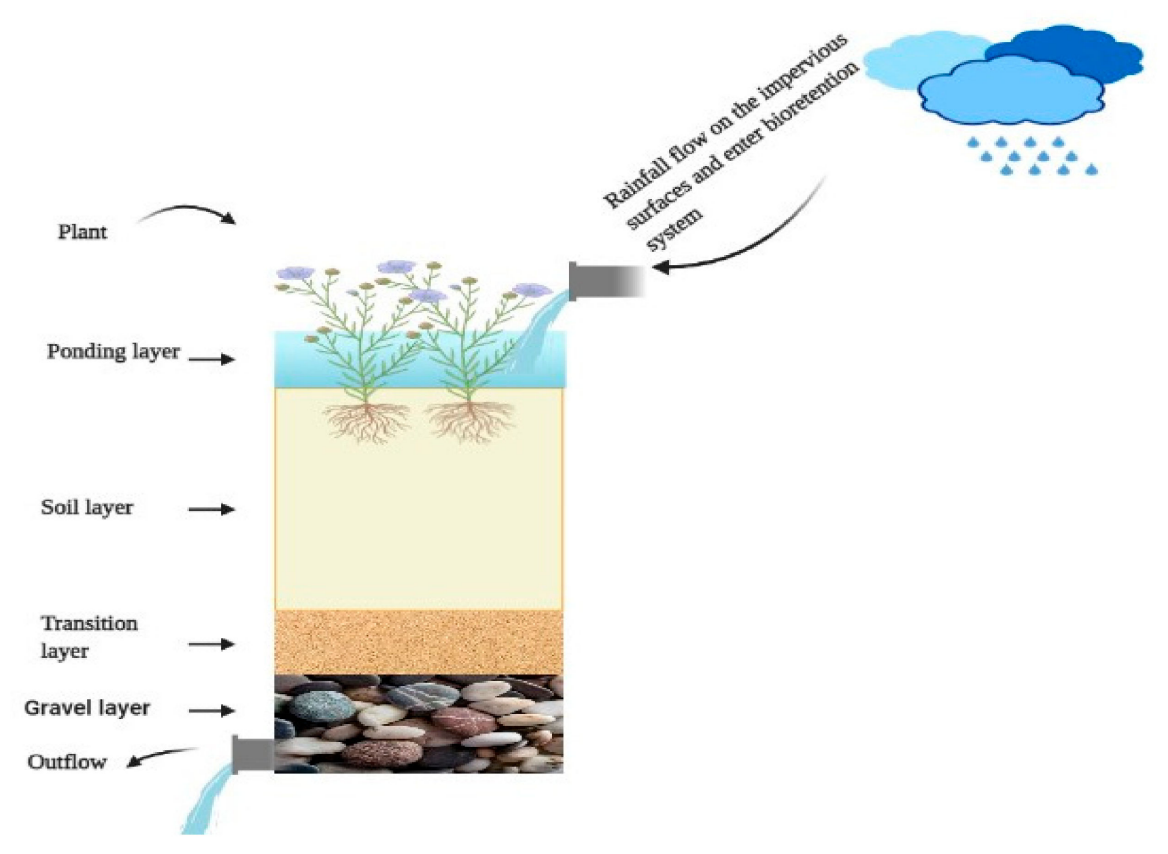

Figure 2. Traditional bioretention system.

\subsection{Nitrogen Removal Process in Bioretention System}

Total nitrogen (TN) includes dissolved organic nitrogen (DON), Ammonium $\left(\mathrm{NH}_{4}\right)$, Nitrate $\left(\mathrm{NO}_{3}\right)$, Nitrite $\left(\mathrm{NO}_{2}\right)$, and particulate organic nitrogen (PON) [47]. The main transformation processes of nitrogen in bioretention system occur through assimilation, adsorption, ammonification (mineralization), nitrification, and denitrification [4,25]. In the assimilation process, inorganic nitrogen forms $\left(\mathrm{NH}_{4}, \mathrm{NO}_{2}, \mathrm{NO}_{3}\right)$ are converted into an organic form in the plant biomass through plant uptake [48]. The adsorption process removes the $\mathrm{NH}_{4}$ form through soil media. Nitrification (aerobic condition) is the biological oxidation of ammonium to nitrite and nitrate. The converted $\mathrm{NO}_{3}$ from nitrification and runoff is transformed into nitrous oxide $\left(\mathrm{N}_{2} \mathrm{O}\right)$, nitric oxide $(\mathrm{NO})$, and dinitrogen gas $\left(\mathrm{N}_{2}\right)$ via the denitrification process (anoxic condition) [49]. Microorganisms play a vital role in nitrification and denitrification reactions. Many environmental conditions are required to achieve the denitrification process through soil media. These conditions include available $\mathrm{N}$, organic carbon, sub-toxic or anoxic conditions, and available denitrifies [50]. The denitrification process removes about $33.5 \%$ of dissolved nitrogen [51]. The stormwater should flow through the aerobic and anaerobic zones with adequate retention time to complete each process [29]. The incomplete denitrification process is the reason for the leaching and instability of $\mathrm{N}$ removal [23]. Figure 3 shows the nitrogen removal process in the bioretention system. 


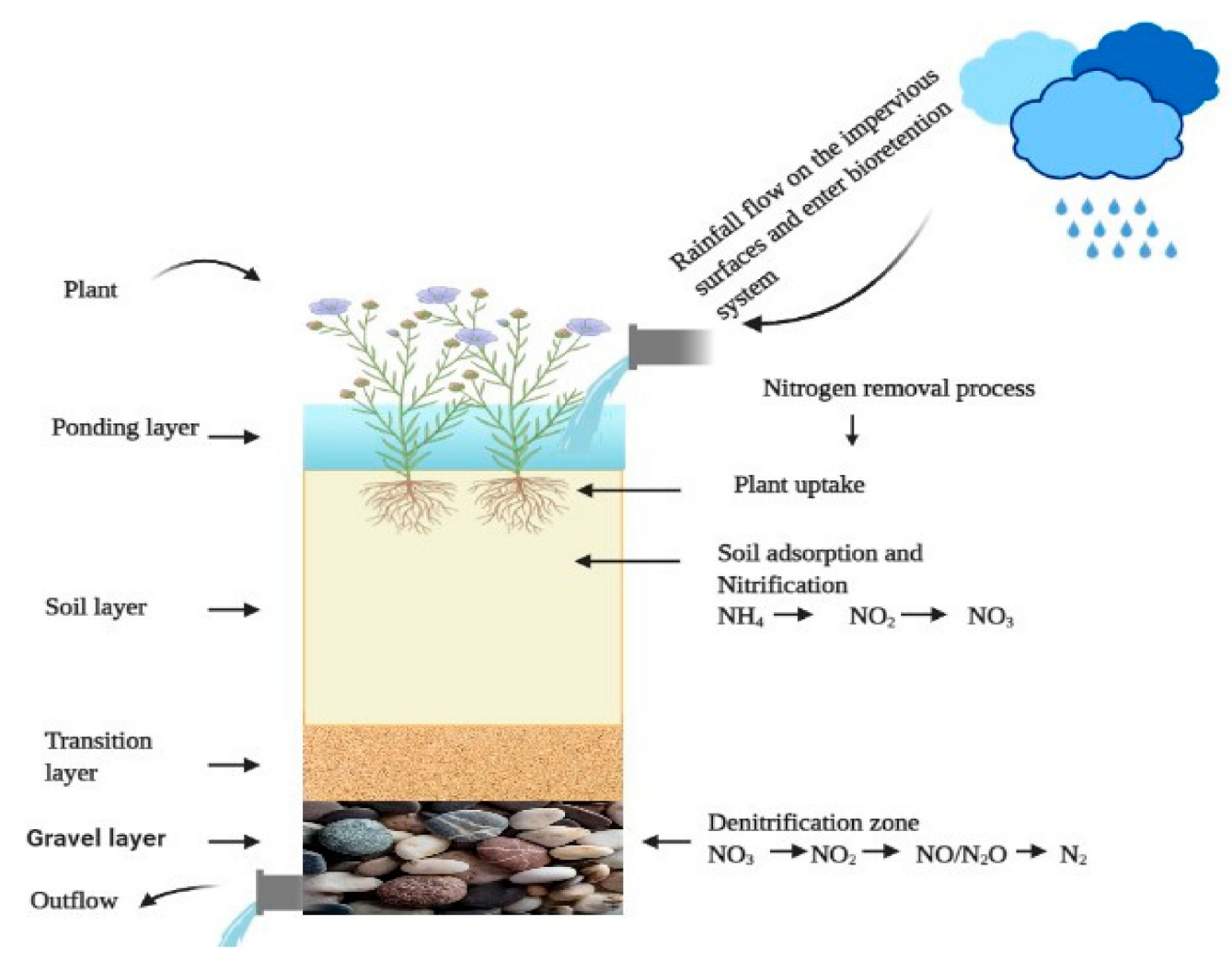

Figure 3. The nitrogen removal process in the bioretention system.

\subsection{Performance of Bioretetnion System}

One of the main issues of stormwater is non-point source pollutants caused by stormwater runoff passing over impermeable surfaces (parks, buildings, roads). The concentration of non-point source pollutants is one of the main factors affecting the performance of bioretention. The common pollutants that characterize stormwater include total suspended solids (TSS), total nitrogen (TN), ammonium $\left(\mathrm{NH}_{4}\right)$, nitrate $\left(\mathrm{NO}_{3}\right)$, nitrite $\left(\mathrm{NO}_{2}\right)$, and total phosphorus (TP). These pollutants are significantly affected by geographical features of the location along with meteorological (rainfall intensity, rainfall duration, and runoff volume), land use (commercial, industrial, and agricultural), and geological (soil type and bedrock geology) factors [1,10,52-54]. Considering the types of impervious surfaces is not sufficient for indicating stormwater quality. Beck et al. [55] revealed that the links between the impervious surface, the type of green land cover, and the type of buildings in these areas are accurate indicators of stormwater quality. However, the amount of nutrients is also influenced by the catchment area, the percentage of natural surfaces, surrounding land use, and rainfall depth [56]. The highest pollutant concentration of a specific location should be considered when designing a bioretention system [57]. Design features such as climate factors (including rainfall intensity, temperature, dry and wet periods, rainfall duration, and first-flush raining) and hydrologic conditions (including runoff volume, hydraulic conductivity, flowrate, bioretention surface area, and catchment area) are also important factors that should be considered to achieve the best efficiency.

\subsection{Influence of Filter Media}

The filter media is an essential factor involved in the inadequacy of bioretention nutrient removal. The filter media provides microbial conditions and electron donors as well as the nutrient sorption medium [29]. Generally, the filter media is comprised of soil and sand with different portions depending on the design manuals. Some guidelines propose using net soil, while others recommend sand and loam sand. The sandy soil is considered to have low water content and high porosity. Furthermore, coarser media affects plant growth due to the lower moisture content and lesser water holding capacity [44]. 
Sand media and sandy loam are used in many countries with high annual precipitation to increase the filtration rate [20]. The sand portion increment creates voids in the media and facilitates the infiltration process. Using clay or loam soil causes a low infiltration rate, collaging pollutants, high water content, and the collapse of the bioretention system due to decreasing soil porosity [13]. Clay or loam soil is used in temperate countries such as the USA, Australia, and China [58-60]. These countries have annual precipitation lower than tropical countries [28]. The media composition depends on the climate conditions and precipitation of the region. Overall, sandy loam media is preferred to remove nitrogen (N) $[61,62]$. Sand and sandy loam are the most popular for enhancing $\mathrm{N}$ and nitrate $\left(\mathrm{NO}_{3}\right)$ removal [23,63]. Nitrate $\left(\mathrm{NO}_{3}\right)$ removal occurs in filter media via soil cation exchange [64]. Applying different particle sizes in filter media helps achieve the best consistency and good nutrient removal, as well as providing the best water holding capacity for the plant's survival. Furthermore, the nutrient concentration in filter media before raining affects the variance in the pollutant removal via the bioretention system [65].

On the other hand, the filter media's depth plays a significant role in pollutant removal. Deeper filter media achieves greater total nitrogen (TN) reduction [66]. More in-depth soil media requires greater excavation efforts and costs. The filter zone must range from 150 to $1200 \mathrm{~mm}$, and this also depends on the contribution area [38]. Takaijudin et al. [66] found that the minimum depth of a bioretention system required to achieve good nutrient removal was $400 \mathrm{~mm}$. Generally, filter media depth ranges from $400 \mathrm{~mm}$ to $1200 \mathrm{~mm}$, and the depth also depends on the type of plant and pollutant concentration [67]. Table 2 shows the depth and composition of filter media in different manuals. It also demonstrates the difference in filter media depth, which is related to climate, the type of vegetation, and root depth.

Table 2. Filter media details and target nitrogen removal in different manuals.

\begin{tabular}{|c|c|c|c|c|}
\hline Manual & Soil Description (\%) & Soil Depth (mm) & TN Removal (\%) & Ref. \\
\hline Bioretention Technical Design Guidelines & 100 Sand loam & $500-1000$ & 45 & [68] \\
\hline $\begin{array}{l}\text { Urban Stormwater Management } \\
\text { Manual, Malaysia }\end{array}$ & $\begin{array}{c}\text { (20-25) Topsoil } \\
\text { (50-60) Sand } \\
(12-20) \text { Leaf compost }\end{array}$ & $450-1000$ & 50 & {$[20]$} \\
\hline $\begin{array}{l}\text { Adoption Guidelines for Stormwater } \\
\text { Biofiltration Systems, Australia }\end{array}$ & $\begin{array}{l}\text { (10-30) Fine sand } \\
(40-60) \text { Coarse sand } \\
(0-10) \text { Coarse sand }\end{array}$ & $>500$ & $>50$ & [69] \\
\hline Bioretention Manual, Maryland & $\begin{array}{c}\text { (20-30) Topsoil } \\
\text { (50-30) Sand } \\
(20-30) \text { Leaf compost. }\end{array}$ & $750-1200$ & $33-66$ & [58] \\
\hline New Jersey Stormwater BMP Manual, USA & $\begin{array}{l}\text { (85-95) Sand } \\
(2-5) \text { Silt clay } \\
\text { (3-7) Organics }\end{array}$ & $450-600$ & 30 & [70] \\
\hline $\begin{array}{l}\text { Pennsylvania stormwater best management } \\
\text { practices manual, USA }\end{array}$ & $\begin{array}{l}(20-30) \text { Compost } \\
(70-80) \text { Soil bases }\end{array}$ & $>450$ & 30 for $\mathrm{NO}_{3}$ & [59] \\
\hline Guide of Sponge City Construction, China & Plant soil & 250-1200 & $\mathrm{N} \backslash \mathrm{A}$ & {$[60]$} \\
\hline ABC waters design guidelines, Singapore & Sandy loam & $400-600$ & 45 & [71] \\
\hline North Carolina Stormwater Design Manual & $\begin{array}{l}(85-88) \text { Sand } \\
(8-12) \text { Fines } \\
(3-5) \text { Organic }\end{array}$ & $600-900$ & $35-60$ & [72] \\
\hline
\end{tabular}

\subsection{Influence of mulch Layer}

The mulch layer is located on the top of the engineered soil, which is comprised of decaying leaves, bark, or compost. It provides organic matter for plant survival and prevents the surface layer from clogging due to fine particles in runoff [73]. The depth of the mulch layer is recommended in the range from 50 to $100 \mathrm{~mm}$ [20,73]. Many researchers 
have eliminated the mulch layer and substituted it by mixing compost or additives within soil media $[63,74]$. Applying a mulch layer to the top portion of a bioretention system can enhance nitrogen removal $[65,75]$.

Goh et al. [28] mentioned that the mulch layer can be excluded when applying bioretention systems in tropical countries because the high rainfall and a short dry period mean the soil is wet most of the time and provides water for plant survival. Moreover, sandy soil is used largely in tropical regions and has a high porosity and experiences less clogging compared with the clay soil that has been used in temperate countries. The mulch layer maintains moisture conditions for plants during dry periods. The use of mulch in the top layer of the system is recommended in temperate regions such as the USA and Australia, which have a longer dry period than tropical regions [76,77].

\subsection{Influence of Vegetation}

Vegetation is essential to bioretention systems. It slows down runoff flow, provides comfortable atmospheric conditions, and creates an aesthetic view, among other benefits. Plants also absorb pollutants, minimizing pollution levels and enhancing microbial activity [78-80]. They also help to manage stormwater quality $[46,51,81]$ in bioretention systems by reducing total nitrogen (TN) (by 59-79\%) [6] and $\mathrm{NO}_{x}\left(\mathrm{NO}_{3}, \mathrm{NO}_{2}\right)$ levels [82]. Although plants enhance nitrogen $(\mathrm{N})$ removal through assimilation [26], they also contribute to the uptake of $57 \%$ (from $95.4 \%$ ) of all dissolved $\mathrm{N}$ removal [51]. Plant-containing bioretention systems achieve an $\mathrm{NO}_{\mathrm{x}}$ removal rate of $54 \%$ (compared to $15 \%$ for systems with no plants) [26].

The nutrient uptake of plants is directly influenced by several factors, including root structure, density, plant size [79], biomass, growth rate, and soil media nutrients [83]. Long roots are perforated in dry climates [84]. As a plant's roots extend deeper into the soil, the assimilation process is enhanced, thus increasing nitrogen retention $[6,85]$. Also, the physical and chemical properties of soil can change significantly based on vegetation type [86]. Interestingly, the high density and long roots of the plant lead to high nitrification and the denitrification of bacteria, which increases nutrient removal [77,87]. Furthermore, high biomass and high growth rate promote nutrient removal [88]. Plant selection depends on plants' resistance to environmental conditions, such as dry periods, and their ability to treat pollutants under such conditions [79]. Without vegetation, biofiltration systems experience collaging problems and a loss of porosity in filter media over time [89,90]. Meanwhile, plant roots increase filter media porosity and can prevent collage nutrients [91]. Plants can also affect hydrologic factors, such as infiltration and hydraulic conductivity, in biofiltration systems $[82,92-94]$. Studies indicate that vegetated systems have a higher infiltration rate than unvegetated systems [37,95]. Moreover, planted systems are more permeable than unplanted ones [87]. The hydraulic conductivity of a bioretention system can be affected by the type and morphology of plant roots [95]. For example, silky roots (which overlap) decrease hydraulic conductivity, whereas thick roots (which do not overlap) result in better performance $[82,95]$. Furthermore, plants differ significantly in terms of removal efficiency, and this factor is critical to plant selection [96]. It is ideal to select an appropriate native plant because such plants have already adapted to the local environmental conditions [97]. Another important factor is plant diversity, as diversity improves the performance of bioretention systems, especially concerning $N$ removal $[87,90,98,99]$. Thus, multispecies planting can help bioretention systems resist variable environment conditions [100]. Wu et al. [63] found that a bioretention system containing two plant species removed more $\mathrm{NO}_{3}$ and $\mathrm{NH}_{4}$ than a system with only one species. Specifically, mixing deep-rooted species with shallow-rooted species ensures the removal of pollutants from multiple filter media layers $[61,101]$.

\section{Common Approaches to Nitrogen Removal in Bioretention}

This section discusses the popular approaches for enhancing bioretention systems and simultaneously describes the benefits and disadvantages of each approach. 


\subsection{Saturated Zone}

The gravel layer is a lower part of the conventional system of bioretention that contains fine, medium, or coarse-grade gravel. This layer is the more porous layer of the bioretention system. The primary function of the gravel layer is to collect and transport the treated water to the outlet pipe or surrounding soil, as well as to prevent the washout of engineered soil $[20,102]$.

The inclusion of a saturated zone (SZ) in the bioretention system has a positive effect on the reduction of nitrogen $(\mathrm{N})$, especially nitrate $\left(\mathrm{NO}_{3}\right)$ and nitrite $\left(\mathrm{NO}_{2}\right)$. Among the research community, this is a well-known principle. The SZ is used mainly to provide anaerobic conditions as well as plant survival between events in the dry season [102,103]. The main reason for inadequate $\mathrm{N}$ removal in the traditional bioretention system is the lack of a denitrification process and anaerobic condition [45,67]. An anaerobic condition is essential for $\mathrm{NO}_{3}$ removal to complete the deoxidation or denitrification process. The denitrification process is the process of releasing gaseous nitrogen in the forms of $\mathrm{N}_{2} \mathrm{O}$, $\mathrm{NO}$, and $\mathrm{N}_{2}$ [102]. Several published studies describe the link between the removal of $\mathrm{N}$ and SZ via the provision of an anoxic zone to improve microbial activity $[21,63,76,104]$. The denitrification process is unstable; in some cases, it has been found that there was no significant effect of SZ on TN removal [12,105]. This may be due to the presence of a carbon source in the soil media that has been converted into $\mathrm{NH}_{4}$. Furthermore, some studies have found that SZ does not affect NOX removal (amendment media and SZ) [106,107]. The presence of carbon sources has the main role in SZ enhancement $[26,108,109]$. To improve the denitrification process, different forms of carbon sources have been used, including woodchips, newspapers, sawdust, and sulfur [109-111]. Adding a carbon source within $\mathrm{SZ}$ enhanced TN $[26,108]$. The presence of SZ can also enhance $\mathrm{TN}$ and $\mathrm{NO}_{3}$ removal, whereas $\mathrm{NH}_{4}$ reduction is not dependent on the presence of a saturated zone (SZ) [51]. On the other hand, $\mathrm{NH}_{4}$ removal in a bioretention system without a saturated zone is more efficient. Increasing the depth of the saturated zone has a negative effect on $\mathrm{NH}_{4}$ removal [108]. Up to $95.42 \%$ of $\mathrm{NH}_{4}$ is retained in the soil media [112]. Different saturated zone depths have been suggested, ranging from 150 to $600 \mathrm{~mm}[11,23,111,113]$. In terms of cost, $\mathrm{Xu}$ and Zhang [113] recommended that the best SZ depth for TN removal was $450 \mathrm{~mm}$, and including SZ would mean more excavation work and higher costs. Table 3 shows a list of studies with different SZ depths and removal efficiency. 
Table 3. Pollutant removal efficiency in the bioretention system enhanced with the SZ under different sites.

\begin{tabular}{|c|c|c|c|c|c|c|c|c|c|}
\hline \multirow{2}{*}{ Plant } & \multirow{2}{*}{ Depth SZ (mm) } & \multirow{2}{*}{ Soil Type (\%) } & \multirow{2}{*}{ Carbon Source (\%) } & \multirow{2}{*}{ Type of Study } & \multicolumn{3}{|c|}{ Removal Efficiency (\%) } & \multirow{2}{*}{$\begin{array}{c}\text { Site } \\
\text { Location }\end{array}$} & \multirow{2}{*}{ Ref } \\
\hline & & & & & TN & $\mathrm{NO}_{3}$ & $\mathrm{NH}_{4}$ & & \\
\hline $\begin{array}{c}\text { Bulrushes (Phragmites } \\
\text { australis) }\end{array}$ & $200-600$ & $\begin{array}{l}\text { sandy loam:sand:peat moss } \\
(50: 40: 10)\end{array}$ & Newspaper 5\% & Column & $35-73$ & $-23-62$ & 80 & China & [111] \\
\hline No & 150 & $\begin{array}{l}\text { Silt + clay } \\
(70: 30)\end{array}$ & No & Field & 68 & - & - & USA & [114] \\
\hline Carex appressa & 300 & $\begin{array}{l}\text { loamy sand or Skye sand } \\
\text { filter media }\end{array}$ & No & Column & $77-96.5$ & - & $95-99.7$ & Australia & [115] \\
\hline Hymenocallis speciosa & 200-300 & $\begin{array}{l}\text { Sandy loam:sand } \\
(50: 50)\end{array}$ & Wood chips $5 \%$ & mesocosms & $19-74$ & - & $54-91$ & China & [108] \\
\hline $\begin{array}{l}\text { Radermachera hainanensis } \\
\text { Merr, Ophiopogon japonica }\end{array}$ & $400-600$ & $\begin{array}{l}10 \text { local red soil and } 80 \\
\text { fine sand }\end{array}$ & No & Column & $68.36-83 \%$ & $43.03-79.5$ & $95.42-97.69$ & China & [112] \\
\hline $\begin{array}{c}\text { Dianella revoluta } \\
\text { (Blueberry lily), } \\
\text { Microlaena stipoides } \\
\text { (Weeping Grass), Carex } \\
\text { appressa (Tall sedge) }\end{array}$ & 450 & Sandy loam & No & Mesocosms & $-150-65$ & - & - & Australia & [116] \\
\hline $\begin{array}{c}\text { Buffalograss (Buchloe } \\
\text { dactyloides), Big Muhly } \\
\text { (Muhlenbergia lindheimeri). }\end{array}$ & 150 & $\begin{array}{c}\text { Sand:Silt:Clay } \\
\quad(88: 10: 2) \\
(73: 18: 9) \\
(94: 2: 4)\end{array}$ & $\begin{array}{c}\text { Shredded } \\
\text { hardwood bark }\end{array}$ & Column & $59-79$ & - & - & Australia & {$[6]$} \\
\hline $\begin{array}{l}\text { Baumea juncea, Melaleuca } \\
\text { lateritia, Baumea rubiginosa } \\
\text { and Juncus subsecundus }\end{array}$ & 300 & Sandy loam & Jarrah woodchips & Column & 93 & 67 as $\mathrm{NO}_{\mathrm{X}}$ & 95 & Australia & [81] \\
\hline No & 100 & $\begin{array}{l}\text { Sand:Biochar } \\
(7: 3)\end{array}$ & No & Column & $20-30$ & $50-60$ & $50-60$ & Stanford & [104] \\
\hline No & 559 & $\begin{array}{c}\text { Sand:Topsoil:Compost } \\
(6: 2: 2)\end{array}$ & No & Column & - & $42-63$ & - & USA & [117] \\
\hline
\end{tabular}




\subsection{Filter Media Additives}

Recently, it has been suggested that additives can be used to enhance filter media because they are known to be effective in eliminating nitrogen $(\mathrm{N})$. Waste products are mainly used to improve bioretention efficiency because they are cost-effective, require less effort, and can solve environmental issues. Several types of additives are used as a layer or mixed with soil media, including newspapers, woodchips, sawdust, wheat straw, Skye sand, shredded hardwood bark mulch, and water treatment residuals (WTR). In addition, the bilayer media concept is also used to enhance the bioretention system; it involves different layers of modifier media with various mechanical and chemical properties. The wide range of layer properties including porosity, permeability, particle size, water holding capacity, moisture content, bulk density, $\mathrm{CEC}$, and $\mathrm{pH}$ would provide adsorption, nitrification, and denitrification conditions [7,12,39,75,118,119]. The bilayer of bioretention forms an anaerobic condition and increases nitrogen removal by applying a low-porosity layer in the lower portion of the media, which results in best nitrogen removal $[39,105]$. The less-permeable layer in the bottom of the bioretention media decreases water flow, thereby impeding the diffusion of oxygen and forming an anoxic zone [105].

Furthermore, the available carbon source in this layer promotes the denitrification process $[27,39,120]$. The denitrification process could be provided by the inclusion of a lowporosity layer at the bottom of the soil media [39]. Providing denitrification conditions in soil media is encouraged, especially in wet climates [28]. The inclusion of a saturated zone (SZ) in the bioretention system is not necessary for tropical countries with rainfall depth of over $2000 \mathrm{~mm}[28,76,103]$. Overall, amendment materials improve nitrogen removal and offer a promising approach for bioretention enhancement [106]. The common additives that have been used as absorptive, nitrifier, and denitrifier materials are shown in Table 4. However, most studies on this topic do not study the removal of nitrate and nitrite and focus only on the reduction of TN. 
Table 4. The characteristics and removal efficiency investigated in amended bioretention systems at different sites.

\begin{tabular}{|c|c|c|c|c|c|c|c|c|c|}
\hline \multirow{2}{*}{ Additives in Filter Media } & \multirow{2}{*}{ Plant } & \multirow{2}{*}{ Soil Description (\%) } & \multirow{2}{*}{ SZ } & \multirow{2}{*}{ Type of Study } & \multicolumn{3}{|c|}{ Removal Efficiency (\%) } & \multirow{2}{*}{$\begin{array}{c}\text { Site } \\
\text { Location }\end{array}$} & \multirow{2}{*}{ Ref. } \\
\hline & & & & & TN & $\mathrm{NO}_{3}$ & $\mathrm{NH}_{4}$ & & \\
\hline $\mathrm{WTR}^{1}, \mathrm{GZ}^{2}, \mathrm{M}^{3}, \mathrm{~F}^{4}, \mathrm{~V}^{5}, \mathrm{~T}^{6}, \mathrm{C}^{7}$ & Buxus sinica and Lolium perenne $\mathrm{L}$. & Soil:Sand:Woodchips (65:30:5) & No & Column & $>63.4$ & - & - & China & {$[48]$} \\
\hline Organic matter & $\begin{array}{l}\text { Phragmites australis (Common Reed); Typ-Typha latifolia (Broadleaf } \\
\text { Cattail); Scv-Scirpus validus (Soft-stem Bulrush); Sca-Scirpus } \\
\text { acutus (Hard-stem Bulrush); Cap—Carex praegracilis (Common field } \\
\text { sedge); Cam-Carex microptera (Smallwing Sedge) }\end{array}$ & $\begin{array}{l}\text { Sand:Silt:Clay }(91.7 \pm 0.3) \\
\quad(2.3 \pm 0.3) \\
\quad(6.0 \pm 0.0)\end{array}$ & No & Plastic containers & $48-52$ & - & - & China & [121] \\
\hline Sorbtive media & $\begin{array}{l}\text { Daylilies 'Stella d'Oro' (Hemerocallis spp.) and Switchgrass } \\
\text { 'Shenandoah' (Panicum virgatum); Butterfly Milkweed 'Tuberosa' } \\
\text { (Asclepias tuberosa), Windflower (Anemone canadensis), Columbine } \\
\text { (Aquilegia canadensis), New England Aster 'Purple Dome' } \\
\text { (Symphyotrichum novae-angliae), Blue False Indigo 'Capsian' and } \\
\text { 'Midnight Prairiebliss' (Baptisia australis), Sneezeweed 'Red+Gold' } \\
\text { (Helenium autumnale), and Cardinal Flower (Lobelia cardinalis) }\end{array}$ & $\begin{array}{l}\text { Sand:Compost } \\
\quad(60: 40)\end{array}$ & No & Field & 67 & - & - & USA & {$[76]$} \\
\hline $\begin{array}{l}\text { peat soil, coconut chaff, } \\
\text { vermiculite, medical stone, Fly ash, } \\
\text { green zeolite, }\end{array}$ & Buxus microphylla, Ophiopogon japonicus & Soil:Sand:Wood chips (30:65:5) & No & Column & - & - & - & China & [122] \\
\hline hardwood mulch & prairie cord grass (Spartina pectinata), sumpweed (Iva annua). & $\begin{array}{c}\text { Sand:shredded } \\
\text { hardwood:sandy loam } \\
(50: 20: 70)\end{array}$ & No & Field & 56 & 33 & - & USA & [123] \\
\hline $\mathrm{N} \backslash \mathrm{A}$ & $\begin{array}{l}\text { Ti plant (Cordyline fruticosa), Rosea variegata (Graptophyllum pictum), } \\
\text { Bamboo grass (Bambusoideae), Umbrella plant (Cyperus alternifolius) }\end{array}$ & Sand & No & Column & $40.3-45.5$ & - & - & Malaysia & [22] \\
\hline WTR & $\mathrm{N} \backslash \mathrm{A}$ & Loamy sand & No & Field & 41 & -45 & - & USA & [27] \\
\hline Wood chips, Bottom ash & No & Sand & No & Lab-scale- container & $40-55$ & - & - & Korea & {$[124]$} \\
\hline $\begin{array}{l}\text { Aquatic plant detritus, Terrestrial } \\
\text { plant detuitus. }\end{array}$ & No & Sandy loam & No & Column & $60-63$ & - & $95-97$ & China & [125] \\
\hline WTR, coconut fiber, RCA ${ }^{8}$ & No & Sandy & No & Column & 59.8 & - & - & Singapore & [126] \\
\hline Fly ash, crushed straw & Fescue (Festuca ovina L.) & $\begin{array}{c}\text { Sand:fly ash:crushed straw } \\
(90: 5: 5)\end{array}$ & No & Column & $76.8-95.3$ & $87.5-97.4$ & $85.1-98.3$ & China & [39] \\
\hline
\end{tabular}

${ }^{1}$ water treatment residuals; ${ }^{2}$ Green zeolite; ${ }^{3}$ medical stone; ${ }^{4}$ fly ash; ${ }^{5}$ vermiculite; ${ }^{6}$ turfy; ${ }^{7}$ coconut husk; ${ }^{8}$ recycled concrete aggregate. 


\subsection{Combination of Modified Media and Saturated Zone}

The combination of modified filter media (as a mixture or as a layer) and the saturated zone (SZ) is the latest development in nitrogen removal enhancement [11]. This configuration is considered the best since the development has improved the conditions of nitrification and denitrification [127]. Nitrification occurs through enhanced soil media, especially in the dry season, and denitrification via SZ. In this approach, the process of nitrogen removal occurred in steps through soil media, where ammonium $\left(\mathrm{NH}_{4}\right)$ was adsorbed in the upper part of the filter media and transferred by the nitrification process to nitrate $\left(\mathrm{NO}_{3}\right)$ [128]. The addition of additives containing a carbon source increases $\mathrm{NH}_{4}$ adsorption. Furthermore, these additives improve the microbial activity of soil media, thereby enhancing the removal of $\mathrm{NO}_{3}$ by microorganism assimilation and dissimilation [106]. Microbial activity plays a critical role in minimizing $\mathrm{NO}_{3}$ compared with soil adsorption [129]. The combination of the saturated zone and modified media in the bioretention system promotes the nitrogen cycle $[11,27,120]$. Emma V. Lopez-Ponnada et al. [26] conducted a field study and compared the modified system (combined woodchips layer with SZ) and the traditional bioretention system without any modification. The findings have shown that removals of $\mathrm{NH}_{4}$ and $\mathrm{NO}_{\mathrm{X}}\left(\mathrm{NO}_{2}, \mathrm{NO}_{3}\right)$ in the modified system were $83 \%$ and $81 \%$, respectively, and for the traditional system $74 \%$ and $29 \%$, respectively. Some of the studies applied modifiers as a mixture with the media [130]. Xiong et al. [106] compared the performance of the traditional system and retrofitted media with biochar or iron-coated biochar (ICB) and rice husk (RHB). The results have shown that with the inclusion of the $\mathrm{SZ}$, the enhancement media with ICB and RHB give a better performance than the traditional system. The efficiency of the amendment material depends on the CEC and surface area [106]. Another study was undertaken using various materials for waste modification, including flyash, shells, ceramsite, pyrite, quartz, grinding slag, bottom ash, electric arc furnace slag (EAFS), and basic oxygen furnace slag. The results showed that the retrofitted media with bottom ash yielded the best performance with TN removal, indicating an improvement from $58 \%$ to $70 \%$ [11]. At present, limited research has been conducted to examine the feasibility of this strategy. Table 5 summarizes recent studies that have used this method. Almost all these studies achieved significant removal of $\mathrm{N}$ forms.

Table 5. Recent studies on the combination method.

\begin{tabular}{|c|c|c|c|c|c|c|c|c|}
\hline \multirow{2}{*}{$\begin{array}{l}\text { Soil Depth } \\
\quad(\mathrm{mm})\end{array}$} & \multirow{2}{*}{$\begin{array}{c}\text { Soil Description } \\
\text { (Layered in } \mathrm{mm} \text {, Mixture in \%) }\end{array}$} & \multirow{2}{*}{$\begin{array}{l}\text { Type of } \\
\text { Media }\end{array}$} & \multirow{2}{*}{$\begin{array}{l}\text { SZ Depth } \\
(\mathrm{mm})\end{array}$} & \multirow{2}{*}{ Plant } & \multicolumn{3}{|c|}{ Removal Efficiency (\%) } & \multirow[b]{2}{*}{ Ref. } \\
\hline & & & & & TN & $\mathrm{NH}_{4}$ & $\mathrm{NO}_{3}$ & \\
\hline 500 & $\begin{array}{c}\text { Sandy loam:Peat moss: } \mathrm{CaCO}_{3} \\
(95: 5)\end{array}$ & Mixture & 300 & Phragmites australise & - & $13-92$ & $-24-53$ & [131] \\
\hline 457 & $\begin{array}{l}\text { Sand:Biochar } \\
(65: 35)\end{array}$ & Mixture & 305 & $\begin{array}{l}\text { Muhlenbergia (Muhly } \\
\text { grass) }\end{array}$ & 95 & - & - & [132] \\
\hline 800 & $\begin{array}{c}\text { Sandy loam:WTR } \\
(85: 15)\end{array}$ & Mixture & $400-800$ & Iris lactea var chinensis & 75 & $>90$ & 85 & {$[21]$} \\
\hline 950 & $\begin{array}{c}\text { Topsoil:Silica } \\
\text { Sand:Zeolite:Ceramist } \\
(200: 250: 250: 250) \\
\end{array}$ & Layered & 850 & $\begin{array}{l}\text { Zoysia matrella }(\mathrm{ZM}) \\
\text { Iris pseudacorus. }\end{array}$ & $49.8 \pm 22$ & - & - & [63] \\
\hline 605 & $\begin{array}{c}\text { Sand:River rock:Woodchips: } \\
(300: 300: 50)\end{array}$ & Layered & 605 & $\begin{array}{l}\text { dwarf pentas (Pentas } \\
\text { lanceolate), blue daze } \\
\text { (Evolvulus glomeratus) }\end{array}$ & 90 & 83 & $\begin{array}{l}81 \text { as } \\
\mathrm{NO}_{\mathrm{X}}\end{array}$ & {$[26]$} \\
\hline 550 & $\begin{array}{l}\text { Soil:(peat soil, perlite, } \\
\text { vermiculite, cocoanut fiber and } \\
\text { carbonized rice husk) } \\
(90: 10)\end{array}$ & Mixture & 150 & Codiaeum variegatum & $58-70$ & - & - & [11] \\
\hline 1050 & $\begin{array}{l}\text { Soil:sand:ceramsite:quartz } \\
\text { sand:gravel:pyrite:pebble } \\
\text { (400:150:100:100:300) }\end{array}$ & Layered & 350 & No & 89 & 87 & - & [133] \\
\hline 400 & $\begin{array}{l}\text { Mixed sand and surfactant } \\
\text { modified activated carbon }\end{array}$ & Layered & 450 & No & - & - & 94 & [134] \\
\hline
\end{tabular}




\section{Conclusions}

A bioretention system is a green infrastructure system widely introduced in Australia, the U.S., China, and Singapore. The literature has discussed the adequacy of the bioretention system in terms of nitrogen reduction. To achieve good performance, many factors should be considered when designing a bioretention system, such as nitrogen concentration, climate, hydrological factors, land use, and surrounding buildings. Furthermore, soil and plant selection should be appropriate for environmental conditions. Three approaches have been introduced for nitrogen-removal enhancement in a bioretention system. The first is the saturated zone (SZ), which is the most common method and is used worldwide. The use of modifier materials in soil media is the second and less common option. This principle is intended to be implemented in tropical regions with wet soil media and short dry periods. The third strategy is to integrate two previous methods into the same system. This technique has been upgraded recently, including via retrofitting soil media and SZ, which is more effective than previous approaches and less widespread. Further research is needed to study the effectiveness of modification materials and their ability to provide nitrification and denitrification conditions through soil media. Moreover, the merging of retrofitted media and SZ is a recent and revolutionary technique that deserves further research. Overall, previous studies have shown that the bioretention system is a promising tool to improve the quality of stormwater.

Author Contributions: Investigation, original draft preparation, writing, and formal analysis, W.A.; Supervision and review, H.T. and K.W.Y.; funding, H.T.; review and editing, M.O. and A.S.A. All authors have read and agreed to the published version of the manuscript.

Funding: This research was funded by the Fundamental Research Grant Scheme (FRGS) under the Ministry of Higher Education Malaysia with cost centre 015MA0-070.

Institutional Review Board Statement: Not applicable.

Informed Consent Statement: Not applicable.

Data Availability Statement: Not applicable.

Acknowledgments: The authors would like to acknowledge the support given by the Universiti Teknologi PETRONAS.

Conflicts of Interest: The authors declare no conflict of interest.

\section{References}

1. Saraswat, C.; Kumar, P.; Mishra, B.K. Assessment of stormwater runoff management practices and governance under climate change and urbanization: An analysis of Bangkok, Hanoi and Tokyo. Environ. Sci. Policy 2016, 64, 101-117. [CrossRef]

2. United States Environmental Protection Agency (USEPA). 2000 Action Plan Reducing, Mitigating, Control Hypoxia in the Northern Gulf of Mexico; United States Environmental Protection Agency (USEPA): Washington, DC, USA, 2001.

3. Lee, J.H.; Bang, K.W. Characterization of urban stormwater runoff. Water Res. 2000, 34, 1773-1780. [CrossRef]

4. Osman, M.; Yusof, K.W.; Takaijudin, H.; Goh, H.W.; Malek, M.A.; Azizan, N.A.; Ghani, A.A.; Abdurrasheed, A.S. A review of nitrogen removal for urban stormwater runoff in bioretention system. Sustainability 2019, 11, 5415. [CrossRef]

5. Ab, A.; Azamathulla, H.; Liang, T.; Ravikanth, C.H.; Azazi, N.; Siang, C.; Azlan, M.; Yusof, M. Flow pattern and hydraulic performance of the REDAC Gross Pollutant Trap. Flow Meas. Instrum. 2011, 22, 215-224. [CrossRef]

6. Barrett, M.E.; Limouzin, M.; Lawler, D.F. Effects of media and plant selection on biofiltration performance. J. Environ. Eng. (U. S.) 2013, 139, 462-470. [CrossRef]

7. Jiang, C.; Li, J.; Li, H.; Li, Y. Remediation and accumulation characteristics of dissolved pollutants for stormwater in improved bioretention basins. Sci. Total Environ. 2019, 685, 763-771. [CrossRef] [PubMed]

8. Jacklin, D.M.; Brink, I.C.; Dewaal, J. Laboratory method design for investigating the phytoremediation of polluted water. Water SA 2019, 45, 608-615. [CrossRef]

9. Howarth, R.; Paerl, H.W. Coastal marine eutrophication: Control of both nitrogen and phosphorus is necessary. Proc. Natl. Acad. Sci. USA 2008, 105. [CrossRef]

10. Reza, A.; Eum, J.; Jung, S.; Choi, Y.; Owen, J.S.; Kim, B. Export of non-point source suspended sediment, nitrogen, and phosphorus from sloping highland agricultural fields in the East Asian monsoon region. Environ. Monit. Assess. 2016, 188. [CrossRef]

11. You, Z.; Zhang, L.; Pan, S.Y.; Chiang, P.C.; Pei, S.; Zhang, S. Performance evaluation of modified bioretention systems with alkaline solid wastes for enhanced nutrient removal from stormwater runoff. Water Res. 2019, 161, 61-73. [CrossRef] 
12. Hunt, W.F.; Jarrett, A.R.; Smith, J.T.; Sharkey, L.J. Evaluating bioretention hydrology and nutrient removal at three field sites in North Carolina. J. Irrig. Drain. Eng. 2006, 132, 600-608. [CrossRef]

13. Davis, A.P.; Hunt, W.F.; Traver, R.G.; Clar, M. Bioretention technology: Overview of current practice and future needs. J. Environ. Eng. 2009, 135, 109-117. [CrossRef]

14. Jia, H.; Ma, H.; Sun, Z.; Yu, S.; Ding, Y.; Liang, Y. A closed urban scenic river system using stormwater treated with LID-BMP technology in a revitalized historical district in China. Ecol. Eng. 2014, 71, 448-457. [CrossRef]

15. Jia, H.; Yao, H.; Tang, Y.; Yu, S.L.; Zhen, J.X.; Lu, Y. Development of a multi-criteria index ranking system for urban runoff best management practices (BMPs) selection. Environ. Monit. Assess. 2013, 185, 7915-7933. [CrossRef]

16. Jiménez Ariza, S.L.; Martínez, J.A.; Muñoz, A.F.; Quijano, J.P.; Rodríguez, J.P.; Camacho, L.A.; Díaz-Granados, M. A multicriteria planning framework to locate and select Sustainable Urban Drainage Systems (SUDS) in consolidated urban areas. Sustainability 2019, 11, 2312. [CrossRef]

17. Lindsey, G.; Roberts, L.; Page, W. Inspection and maintenance of infiltration facilities. J. Soil Water Conserv. 1992, 47, 481-486.

18. Blecken, G.-T.; Hunt, W.F., III; Al-Rubaei, A.M.; Viklander, M.; Lord, W.G. Stormwater control measure (SCM) maintenance considerations to ensure designed functionality. Urban Water J. 2017, 14, 278-290. [CrossRef]

19. Barrett, M.E. Performance, cost, and maintenance requirements of Austin sand filters. J. Water Resour. Plan. Manag. 2003, 129, 234-242. [CrossRef]

20. Government of Malaysia Department of Irrigation and Drainage. Urban Stormwater Management Manual for Malaysia MSMA, 2nd ed.; Department of Irrigation and Drainage: Kuala Lumpur, Malaysia, 2012; ISBN 9789839304244.

21. Qiu, F.; Zhao, S.; Zhao, D.; Wang, J.; Fu, K. Enhanced nutrient removal in bioretention systems modified with water treatment residuals and internal water storage zone. Environ. Sci. Water Res. Technol. 2019, 5, 993-1003. [CrossRef]

22. Hermawan, A.A.; Talei, A. Removal process of nutrients and heavy metals in tropical biofilters. Proc. E3S Web Conf. EDP Sci. 2018, 65, 5026. [CrossRef]

23. Wang, S.; Lin, X.; Yu, H.; Wang, Z.; Xia, H.; An, J.; Fan, G. Nitrogen removal from urban stormwater runoff by stepped bioretention systems. Ecol. Eng. 2017, 106, 340-348. [CrossRef]

24. You, H. Impact of urbanization on pollution-related agricultural input intensity in Hubei, China. Ecol. Indic. 2016, 62, 249-258. [CrossRef] [PubMed]

25. Collins, K.A.; Lawrence, T.J.; Stander, E.K.; Jontos, R.J.; Kaushal, S.S.; Newcomer, T.A.; Grimm, N.B.; Cole Ekberg, M.L. Opportunities and challenges for managing nitrogen in urban stormwater: A review and synthesis. Ecol. Eng. 2010, 36, 1507-1519. [CrossRef]

26. Lopez-Ponnada, E.V.; Lynn, T.J.; Ergas, S.J.; Mihelcic, J.R. Long-term field performance of a conventional and modified bioretention system for removing dissolved nitrogen species in stormwater runoff. Water Res. 2020, 170, 115336. [CrossRef]

27. Li, L.; Davis, A.P. Urban stormwater runoff nitrogen composition and fate in bioretention systems. Environ. Sci. Technol. 2014, 48, 3403-3410. [CrossRef] [PubMed]

28. Goh, H.W.; Lem, K.S.; Azizan, N.A.; Chang, C.K.; Talei, A.; Leow, C.S.; Zakaria, N.A. A review of bioretention components and nutrient removal under different Climates-Future directions for tropics. Environ. Sci. Pollut. Res. 2019, 26, 1-16. [CrossRef]

29. Lefevre, G.H.; Asce, S.M.; Paus, K.H.; Natarajan, P.; Gulliver, J.S.; Asce, F.; Novak, P.J.; Hozalski, R.M.; Le Fevre, G.H.; Paus, K.H.; et al. Review of dissolved pollutants in urban storm water and their removal and fate in bioretention cells. J. Environ. Eng. 2015, 141. [CrossRef]

30. Davis, A.P.; Shokouhian, M.; Sharma, H.; Minami, C. Laboratory Study of Biological Retention for Urban Stormwater Management. Water Environ. Res. 2001, 73, 5-14. [CrossRef]

31. Lucke, T.; Nichols, P.W.B. The pollution removal and stormwater reduction performance of street-side bioretention basins after ten years in operation. Sci. Total Environ. 2015, 536, 784-792. [CrossRef] [PubMed]

32. Hunt, W.F.; Smith, J.T.; Jadlocki, S.J.; Hathaway, J.M.; Eubanks, P.R. Pollutant removal and peak flow mitigation by a bioretention cell in Urban Charlotte, N.C. J. Environ. Eng. 2008, 134, 403-408. [CrossRef]

33. Davis, A.P. Field performance of bioretention: Hydrology impacts. J. Hydrol. Eng. 2008, 13, 90-95. [CrossRef]

34. Tzoulas, K.; Korpela, K.; Venn, S.; Yli-Pelkonen, V.; Kaźmierczak, A.; Niemela, J.; James, P. Promoting ecosystem and human health in urban areas using Green Infrastructure: A literature review. Landsc. Urban Plan. 2007, 81, 167-178. [CrossRef]

35. Takebayashi, H.; Moriyama, M. Surface heat budget on green roof and high reflection roof for mitigation of urban heat island. Build. Environ. 2007, 42, 2971-2979. [CrossRef]

36. Li, C.; Peng, C.; Chiang, P.C.; Cai, Y.; Wang, X.; Yang, Z. Mechanisms and applications of green infrastructure practices for stormwater control: A review. J. Hydrol. 2019, 568, 626-637. [CrossRef]

37. Lucas, W.C.; Greenway, M. Nutrient retention in vegetated and nonvegetated bioretention mesocosms. J. Irrig. Drain. Eng. 2008, 134, 613-623. [CrossRef]

38. Takaijudin, H.; Ghani, A.; Zakaria, N.A. Challenges and developments of bioretention facilities in treating urban stormwater runoff: A review. Pollution 2016, 2, 489-508.

39. Luo, Y.; Yue, X.; Duan, Y.; Zhou, A.; Gao, Y.; Zhang, X. A bilayer media bioretention system for enhanced nitrogen removal from road runoff. Sci. Total Environ. 2020, 705, 135893. [CrossRef]

40. Poor, C.; Balmes, C.; Freudenthaler, M.; Martinez, A. Role of Mycelium in Bioretention Systems: Evaluation of Nutrient and Metal Retention in Mycorrhizae-Inoculated Mesocosms. J. Environ. Eng. (USA) 2018, 144, 1-7. [CrossRef]

41. Singh, R.P.; Zhao, F.; Ji, Q.; Saravanan, J.; Fu, D. Design and performance characterization of roadside bioretention systems. Sustainability 2019, 11, 2040. [CrossRef] 
42. Davis, A.P.; Shokouhian, M.; Sharma, H.; Minami, C. Water Quality Improvement through Bioretention Media: Nitrogen and Phosphorus Removal. Water Environ. Res. 2006, 78, 284-293. [CrossRef] [PubMed]

43. Lopez, E.V.; Lynn, T.J.; Peterson, M.; Ergas, S.J.; Trotz, M.A.; Mihelcic, J.R. Enhanced Nutrient management of stormwater through a field demonstration of nitrogen removal in a modified bioretention system. In Proceedings of the World Environmental and Water Resources Congress 2016, West Palm Beach, FL, USA, 22-26 May 2016; pp. 60-69.

44. Jiang, C.; Li, J.; Li, H.; Li, Y. An improved approach to design bioretention system media. Ecol. Eng. 2019, 136, 125-133. [CrossRef]

45. Hatt, B.E.; Fletcher, T.D.; Deletic, A. Hydraulic and pollutant removal performance of fine media stormwater filtration systems. Environ. Sci. Technol. 2008, 42, 2535-2541. [CrossRef]

46. Henderson, C.; Greenway, M.; Phillips, I. Removal of dissolved nitrogen, phosphorus and carbon from stormwater by biofiltration mesocosms. Water Sci. Technol. 2007, 55, 183-191. [CrossRef]

47. Taylor, G.D.; Fletcher, T.D.; Wong, T.H.F.; Breen, P.F.; Duncan, H.P. Nitrogen composition in urban runoff-Implications for stormwater management. Water Res. 2005, 39, 1982-1989. [CrossRef]

48. Jiang, C.; Li, J.; Li, H.; Li, Y. Nitrogen retention and purification efficiency from rainfall runoff via retrofitted bioretention cells. Sep. Purif. Technol. 2019, 220, 25-32. [CrossRef]

49. Yao, X.; Xing-hua, M.A. Research Progress on Effect of Nitrogen Form on Plant Growth. J. Agric. Sci. Technol. $2015,17,109-117$.

50. Firestone, M.K.; Davidson, E.A. Microbiologial Basis of NO and N20 production and consumption in soil. Exch. Trace Gases Terr. Ecosyst. Atmos. 1989, 7-21. [CrossRef]

51. Li, L.; Yang, J.; Davis, A.P.; Liu, Y. Dissolved Inorganic Nitrogen Behavior and Fate in Bioretention Systems: Role of Vegetation and Saturated Zones. J. Environ. Eng. (USA) 2019, 145, 1-9. [CrossRef]

52. Wang, J.; Chua, L.H.C.; Shanahan, P. Evaluation of pollutant removal efficiency of a bioretention basin and implications for stormwater management in tropical cities. Environ. Sci. Water Res. Technol. 2017, 3, 78-91. [CrossRef]

53. Wang, J.; Zhao, Y.; Yang, L.; Tu, N.; Xi, G.; Fang, X. Removal of heavy metals from urban stormwater runoff using bioretention media mix. Water 2017, 9, 854. [CrossRef]

54. Kayhanian, M.; Asce, M.; Singh, A.; Suverkropp, C.; Borroum, S. Impact of annual average daily traffic on highway runoff pollutant Concentrations. J. Environ. Eng. 2003, 129. [CrossRef]

55. Beck, S.M.; McHale, M.R.; Hess, G.R. Beyond impervious: Urban land-cover pattern variation and implications for watershed management. Environ. Manag. 2016, 58, 15-30. [CrossRef]

56. Passeport, E.; Hunt, W.F. Asphalt parking lot runoff nutrient characterization for eight sites in North Carolina, USA. J. Hydrol. Eng. 2009, 14, 352-361. [CrossRef]

57. Muerdter, C.P.; Wong, C.K.; Lefevre, G.H. Emerging investigator series: The role of vegetation in bioretention for stormwater treatment in the built environment: Pollutant removal, hydrologic function, and ancillary benefits. Environ. Sci. Water Res. Technol. 2018, 4, 592-612. [CrossRef]

58. Bioretention Manual; Department of Environmental Resources: Prince George's County, MD, USA, 2007.

59. Pennsylvania Stormwater Best Management Practices Manual; Department of Environmental Protection: Harrisburg, PA, USA, 2006.

60. Ulku, M.; Xinxin, S.; van der Lans, M.; Peynado, T.D.; Zheng, J.; Fong, C. Sponge City Multidisciplinary Project; ERQI Sponge City Final Report; Delft University of Technology: Delft, The Netherlands, 2018.

61. Lim, H.S.; Lim, W.; Hu, J.Y.; Ziegler, A.; Ong, S.L. Comparison of filter media materials for heavy metal removal from urban stormwater runoff using biofiltration systems. J. Environ. Manag. 2015, 147, 24-33. [CrossRef] [PubMed]

62. Wang, R.; Zhang, X.; Li, M.H. Predicting bioretention pollutant removal efficiency with design features: A data-driven approach. J. Environ. Manag. 2019, 242, 403-414. [CrossRef]

63. Wu, J.; Cao, X.; Zhao, J.; Dai, Y.; Cui, N.; Li, Z.; Cheng, S. Performance of biofilter with a saturated zone for urban stormwater runoff pollution control: Influence of vegetation type and saturation time. Ecol. Eng. 2017, 105, 355-361. [CrossRef]

64. Cording, A. Evaluating Stormwater Pollutant Removal Mechanisms by Bioretention in the Context of Climate Change. Ph.D. Thesis, The University of Vermont, Burlington, VT, USA, 2016.

65. Jiang, C.; Li, J.; Li, H.; Li, Y. Experimental study of nitrogen removal efficiency of layered bioretention under intermittent or continuous operation. Polish J. Environ. Stud. 2017, 26, 1121-1130. [CrossRef]

66. Takaijudin, H.; Puay, H.T.; Ghani, A.A.; Zakaria, N.A.; Lau, T.L. The Influence of Filter Depths in Capturing Nutrient Contaminants for Non-Vegetated Bioretention Column: A Preliminary Study. In Proceedings of the 36th IAHR World Congress, The Hague, The Netherlands, 2015, 28 June-3 July; p. 986.

67. Brown, R.A.; Hunt, W.F. Impacts of Media Depth on Effluent Water Quality and Hydrologic Performance of Undersized Bioretention Cells. J. Irrig. Drain. Eng. 2011, 137, 132-143. [CrossRef]

68. Department of Environment and Resource Management. Bioretention Technical Design Guidelines; Australian Government: Brisbane, Australia, 2014; ISBN 9780980627893.

69. Cooperative Research Centre for Water Sensitive Cities. Adoption Guidelines for Stormwater Biofiltration Systems; Cooperative Research Centre for Water Sensitive Cities: Melbourne, Australia, 2015; ISBN 9781921912276.

70. NJDEP - New Jersey Department of Environmental Protection. New Jersey stormwater best management practices manual: Chapter 9.1 bioretention systems. In Quantum; NJDEP-New Jersey Department of Environmental Protection: Trenton, NJ, USA, 2016; Volume 1, pp. 2009-2010. ISBN 9193418353. 
71. PUB Public Utilities Board (PUB). Engineering Procedures for ABC Waters Design Features; PUB Public Utilities Board (PUB): Singapore, 2009.

72. North Carolina Department of Environment and Natural Resources-Division of Water Quality. Bioretention. In Stormwater Best Management Practices Manual; North Carolina Department of Environment and Natural Resources—Division of Water Quality: Raleigh, NC, USA, 2007; Chapter 12; pp. 1-30.

73. Trowsdale, S.A.; Simcock, R. Urban stormwater treatment using bioretention. J. Hydrol. 2011, 397, 167-174. [CrossRef]

74. Palmer, E.T.; Poor, C.J.; Hinman, C.; Stark, J.D. Nitrate and Phosphate Removal through Enhanced Bioretention Media: Mesocosm Study. Water Environ. Res. 2013, 85, 823-832. [CrossRef]

75. Wan, Z.; Li, T.; Shi, Z. A layered bioretention system for inhibiting nitrate and organic matters leaching. Ecol. Eng. 2017, 107, 233-238. [CrossRef]

76. Shrestha, P.; Hurley, S.E.; Wemple, B.C. Effects of different soil media, vegetation, and hydrologic treatments on nutrient and sediment removal in roadside bioretention systems. Ecol. Eng. 2018, 112, 116-131. [CrossRef]

77. Willard, L.L.; Wynn-Thompson, T.; Krometis, L.H.; Neher, T.P.; Badgley, B.D. Does it pay to be mature? Evaluation of bioretention cell performance seven years postconstruction. J. Environ. Eng. (USA) 2017, 143, 1-10. [CrossRef]

78. Beecham, S.; Razzaghmanesh, M. Water quality and quantity investigation of green roofs in a dry climate. Water Res. 2015, 70, 370-384. [CrossRef]

79. Read, J.; Wevill, T.; Fletcher, T.; Deletic, A. Variation among plant species in pollutant removal from stormwater in biofiltration systems. Water Res. 2008, 42, 893-902. [CrossRef]

80. Dill, J.; Neal, M.; Shandas, V.; Luhr, G.; Adkins, A. Demonstrating the Benefits of Green Streets for Active Aging; Final Report to EPA; College of Urban and Public Affairs, Portland State University: Portland, OR, USA, 2010; Volume 110.

81. Zhang, Z.; Rengel, Z.; Liaghati, T.; Antoniette, T.; Meney, K. Influence of plant species and submerged zone with carbon addition on nutrient removal in stormwater biofilter. Ecol. Eng. 2011, 37, 1833-1841. [CrossRef]

82. Bratieres, K.; Fletcher, T.D.; Deletic, A.; Zinger, Y. Nutrient and sediment removal by stormwater biofilters: A large-scale design optimisation study. Water Res. 2008, 42, 3930-3940. [CrossRef] [PubMed]

83. Ågren, G.I.; Andersson, F.O. Terrestrial Ecosystem Ecology: Principles and Applications; Cambridge University Press: Cambridge, UK, 2011; ISBN 1107378664.

84. Fan, Y.; Miguez-Macho, G.; Jobbágy, E.G.; Jackson, R.B.; Otero-Casal, C. Hydrologic regulation of plant rooting depth. Proc. Natl. Acad. Sci. USA 2017, 114, 10572-10577. [CrossRef]

85. Gold, A.C.; Thompson, S.P.; Piehler, M.F. Nitrogen cycling processes within stormwater control measures: A review and call for research. Water Res. 2019, 149, 578-587. [CrossRef]

86. Ritz, K. The Architecture and Biology of Soils: Life in Inner Space; Cabi: Wallingford, UK, 2011; ISBN 1845935330.

87. Dagenais, D.; Brisson, J.; Fletcher, T.D. The role of plants in bioretention systems; does the science underpin current guidance? Ecol. Eng. 2018, 120, 532-545. [CrossRef]

88. Muerdter, C.P.; Smith, D.J.; Davis, A.P. Impact of vegetation selection on nitrogen and phosphorus processing in bioretention containers. Water Environ. Res. 2020, 92, 236-244. [CrossRef] [PubMed]

89. Segismundo, E.Q.; Kim, L.-H.; Jeong, S.-M.; Lee, B.-S. A laboratory study on the filtration and clogging of the sand-bottom ash mixture for stormwater infiltration filter media. Water 2017, 9, 32. [CrossRef]

90. Subramaniam, D.N.; Logeswaran, T.; Tharshikka, V.; Nilakshan, B. Dynamics of Clay Particles in Non-vegetated Stormwater Biofilters. Water Air Soil Pollut. 2018, 229, 302. [CrossRef]

91. Leung, A.K.; Garg, A.; Ng, C.W.W. Effects of plant roots on soil-water retention and induced suction in vegetated soil. Eng. Geol. 2015, 193, 183-197. [CrossRef]

92. Virahsawmy, H.K.; Stewardson, M.J.; Vietz, G.; Fletcher, T.D. Factors that affect the hydraulic performance of raingardens: Implications for design and maintenance. Water Sci. Technol. 2014, 69, 982-988. [CrossRef] [PubMed]

93. Gonzalez-Merchan, C.; Barraud, S.; Bedell, J.-P. Influence of spontaneous vegetation in stormwater infiltration system clogging. Environ. Sci. Pollut. Res. 2014, 21, 5419-5426. [CrossRef]

94. Fassman-Beck, E.; Wang, S.; Simcock, R.; Liu, R. Assessing the Effects of Bioretention's Engineered Media Composition and Compaction on Hydraulic Conductivity and Water Holding Capacity. J. Sustain. Water Built Environ. 2015, 1, 1-10. [CrossRef]

95. Le Coustumer, S.; Fletcher, T.D.; Deletic, A.; Barraud, S.; Poelsma, P. The influence of design parameters on clogging of stormwater biofilters: A large-scale column study. Water Res. 2012, 46, 6743-6752. [CrossRef]

96. Read, J.; Fletcher, T.D.; Wevill, T.; Deletic, A. Plant traits that enhance pollutant removal from stormwater in biofiltration systems. Int. J. Phytoremediation 2010, 12, 34-53. [CrossRef]

97. Lim, H.S.; Lu, X.X. Sustainable urban stormwater management in the tropics: An evaluation of Singapore's ABC Waters Program. J. Hydrol. 2016, 538, 842-862. [CrossRef]

98. Ellerton, J.P.; Hatt, B.E.; Fletcher, T.D. Mixed Plantings of Carex appressa and Lomandra longifolia Improve Pollutant Removal over a Monoculture of 'L. longifolia' in Stormwater Biofilters. In Proceedings of the WSUD 2012: Water Sensitive Urban Design, Building the Water Sensitive Community, 7th International Conference on Water Sensitive Urban Design, Melbourne, Australia, 21-23 February 2012; Engineers Australia: Melbourne, Australia, 2012; p. 164.

99. Chen, X.C.; Huang, L.; Chang, T.H.A.; Ong, B.L.; Ong, S.L.; Hu, J. Plant Traits for Phytoremediation in the Tropics. Engineering 2019, 5, 841-848. [CrossRef] 
100. Barron, N.J.; Deletic, A.; Jung, J.; Fowdar, H.; Chen, Y.; Hatt, B.E. Dual-mode stormwater-greywater biofilters: The impact of alternating water sources on treatment performance. Water Res. 2019, 159, 521-537. [CrossRef]

101. Hunt, W.F.; Lord, B.; Loh, B.; Sia, A. Plant Selection for Bioretention Systems and Stormwater Treatment Practices; Springer: Singapore, 2015; ISBN 9789812872449.

102. Payne, E.; Hatt, B.; Deletic, A.; Dobbie, M.; McCarthy, D.; Chandrasena, G. Adoption Guidelines for Stormwater Biofiltration Systems - Summary Report; Cooperative Research Centre for Water Sensitive Cities: Wellington, Australia, 2015.

103. Goh, H.W.; Zakaria, N.A.; Lau, T.L.; Foo, K.Y.; Chang, C.K.; Leow, C.S. Mesocosm study of enhanced bioretention media in treating nutrient rich stormwater for mixed development area. Urban Water J. 2017, 14, 134-142. [CrossRef]

104. Nabiul Afrooz, A.R.M.; Boehm, A.B. Effects of submerged zone, media aging, and antecedent dry period on the performance of biochar-amended biofilters in removing fecal indicators and nutrients from natural stormwater. Ecol. Eng. 2017, 102, 320-330. [CrossRef]

105. Hsieh, C.; Davis, A.P.; Needelman, B.A. Nitrogen Removal from Urban Stormwater Runoff Through Layered Bioretention Columns. Water Environ. Res. 2006, 79. [CrossRef]

106. Xiong, J.; Ren, S.; He, Y.; Wang, X.C.; Bai, X.; Wang, J.; Dzakpasu, M. Chemosphere Bioretention cell incorporating Fe-biochar and saturated zones for enhanced stormwater runoff treatment. Chemosphere 2019, 237, 124424. [CrossRef]

107. Dietz, M.E.; Clausen, J.C. A field evaluation of rain garden flow and pollutant treatment. Water Air Soil Pollut. 2005, 167, 123-138. [CrossRef]

108. Wang, M.; Zhang, D.; Li, Y.; Hou, Q.; Yu, Y.; Qi, J.; Fu, W.; Dong, J.; Cheng, Y. Effect of a submerged zone and carbon source on nutrient and metal removal for stormwater by bioretention cells. Water 2018, 10, 1629. [CrossRef]

109. Lopez-Ponnada, E.V.; Lynn, T.J.; Peterson, M.; Ergas, S.J.; Mihelcic, J.R. Application of denitrifying wood chip bioreactors for management of residential non-point sources of nitrogen. J. Biol. Eng. 2017, 11, 1-14. [CrossRef] [PubMed]

110. Kim, H.; Seagren, E.A.; Davis, A.P. Engineered Bioretention for removal of nitrate from stormwater runoff. Proc. Water Environ. Fed. 2000, 2000, 623-632. [CrossRef]

111. Wang, C.; Wang, F.; Qin, H.; Zeng, X.; Li, X.; Yu, S.-L. Effect of saturated zone on nitrogen removal processes in stormwater bioretention systems. Water 2018, 10, 162. [CrossRef]

112. Fan, G.; Li, Z.; Wang, S.; Huang, K.; Luo, J. Migration and transformation of nitrogen in bioretention system during rainfall runoff. Chemosphere 2019, 232, 54-62. [CrossRef] [PubMed]

113. Xu, X.; Zhang, Q. Sustainable Configuration of Bioretention Systems for Nutrient Management through Life-Cycle Assessment and Cost Analysis. J. Environ. Eng. (USA) 2019, 145, 1-9. [CrossRef]

114. Braswell, A.S.; Winston, R.J.; Hunt, W.F. Hydrologic and water quality performance of permeable pavement with internal water storage over a clay soil in Durham, North Carolina. J. Environ. Manag. 2018, 224, 277-287. [CrossRef]

115. Glaister, B.J.; Fletcher, T.D.; Cook, P.L.M.; Hatt, B.E. Interactions between design, plant growth and the treatment performance of stormwater biofilters. Ecol. Eng. 2017, 105, 21-31. [CrossRef]

116. Zinger, Y.; Blecken, G.T.; Fletcher, T.D.; Viklander, M.; Deletić, A. Optimising nitrogen removal in existing stormwater biofilters: Benefits and tradeoffs of a retrofitted saturated zone. Ecol. Eng. 2013, 51, 75-82. [CrossRef]

117. Yang, H.; McCoy, E.L.; Grewal, P.S.; Dick, W.A. Dissolved nutrients and atrazine removal by column-scale monophasic and biphasic rain garden model systems. Chemosphere 2010, 80, 929-934. [CrossRef] [PubMed]

118. Marvin, J.T.; Passeport, E.; Drake, J. State-of-the-Art Review of Phosphorus Sorption Amendments in Bioretention Media: A Systematic Literature Review. J. Sustain. Water Built Environ. 2020, 6. [CrossRef]

119. Jiang, C.; Li, J.; Ruan, T.; Zhang, Z.; Li, H. Modified media for heavy metals and COD removal from urban stormwater runoff using pilot bioretention systems. Polish J. Environ. Stud. 2019, 28, 3735-3744. [CrossRef]

120. Rahman, M.Y.A.; Nachabe, M.H.; Ergas, S.J. Biochar amendment of stormwater bioretention systems for nitrogen and Escherichia coli removal: Effect of hydraulic loading rates and antecedent dry periods. Bioresour. Technol. 2020, 310, 123428. [CrossRef] [PubMed]

121. Rycewicz-Borecki, M.; McLean, J.E.; Dupont, R.R. Nitrogen and phosphorus mass balance, retention and uptake in six plant species grown in stormwater bioretention microcosms. Ecol. Eng. 2017, 99, 409-416. [CrossRef]

122. Li, J.; Li, L.; Dong, W.; Li, H. Purification effects of amended bioretention columns on phosphorus in urban rainfall runoff. Water Sci. Technol. 2018, 78, 1937-1945. [CrossRef] [PubMed]

123. Chen, X.; Peltier, E.; Sturm, B.S.M.; Young, C.B. Nitrogen removal and nitrifying and denitrifying bacteria quantification in a stormwater bioretention system. Water Res. 2013, 47, 1691-1700. [CrossRef] [PubMed]

124. Kim, H.J.; Choi, J.W.; Kim, T.H.; Park, J.S.; An, B. Effect of TSS removal from stormwater by mixed media column on T-N, T-P, and organic material removal. Water 2018, 10, 1069. [CrossRef]

125. Zhou, Z.; Xu, P.; Cao, X.; Zhou, Y.; Song, C. Efficiency promotion and its mechanisms of simultaneous nitrogen and phosphorus removal in stormwater biofilters. Bioresour. Technol. 2016, 218, 842-849. [CrossRef] [PubMed]

126. Guo, H.; Lim, F.Y.; Zhang, Y.; Lee, L.Y.; Hu, J.Y.; Ong, S.L.; Yau, W.K.; Ong, G.S. Soil column studies on the performance evaluation of engineered soil mixes for bioretention systems. Desalin. Water Treat. 2015, 54, 3661-3667. [CrossRef]

127. Zuo, X.J.; Guo, Z.Y.; Wu, X.; Yu, J. Diversity and metabolism effects of microorganisms in bioretention systems with sand, soil and fly ash. Sci. Total Environ. 2019, 676, 447-454. [CrossRef] 
128. Cho, K.W.; Song, K.G.; Cho, J.W.; Kim, T.G.; Ahn, K.H. Removal of nitrogen by a layered soil infiltration system during intermittent storm events. Chemosphere 2009, 76, 690-696. [CrossRef]

129. Xu, H.J.; Wang, X.H.; Li, H.; Yao, H.Y.; Su, J.Q.; Zhu, Y.G. Biochar impacts soil microbial community composition and nitrogen cycling in an acidic soil planted with rape. Environ. Sci. Technol. 2014, 48, 9391-9399. [CrossRef]

130. Tian, J.; Jin, J.; Chiu, P.C.; Cha, D.K.; Guo, M.; Imhoff, P.T. A pilot-scale, bi-layer bioretention system with biochar and zero- valent iron for enhanced nitrate removal from stormwater. Water Res. 2019, 148, 378-387. [CrossRef] [PubMed]

131. He, K.; Qin, H.; Wang, F.; Ding, W.; Yin, Y. Importance of the Submerged Zone during Dry Periods to Nitrogen Removal in a Bioretention System. Water 2020, 12, 876. [CrossRef]

132. Rahman, M.Y.A.; Truong, N.; Ergas, S.J.; Nachabe, M.H. Biochar-Amended Modified Bioretention Systems for Livestock Runoff Nutrient Management. Florida Water Resour. J. 2020, 42, 44-47.

133. Chen, Y.; Shao, Z.; Kong, Z.; Gu, L.; Fang, J.; Chai, H. Study of pyrite based autotrophic denitrification system for low-carbon source stormwater treatment. J. Water Process Eng. 2020, 37, 101414. [CrossRef]

134. Zhang, J.; Singh, R.P.; Liu, Y.; Fu, D. Design and operation of submerged layer in bioretention for enhanced nitrate removal. J. Water Supply Res. Technol. 2019, 68, 744-756. [CrossRef] 